\title{
Spatial and social conditions for the location of agricultural biogas plants in Poland (case study)
}

\author{
Alina Kowalczyk-Juśko ${ }^{1, *}$, Agnieszka Listosz ${ }^{1}$, and Monika Flisiak $^{l}$ \\ ${ }^{1}$ University of Life Sciences in Lublin, Department of Environmental Engineering and Geodesy, Leszczyńskiego St. 7, 20-069 \\ Lublin, Poland.
}

\begin{abstract}
Biogas production in Poland is controversial. There is a lot of interest in the construction of installations of various scale, and protests of local communities take place at the same time. Residents do not agree to the construction of biogas plants due to the fear of nuisance related to its functioning. This work is a case study of the area of Kamionka - the rural commune in Poland, in terms of the possibility of locating an agricultural biogas plant. The main sources of substrates for biogas production in the commune were determined. When selecting the appropriate location for an agricultural biogas plant, the focus was on the areas designated in the "Study of conditions and directions for spatial development" as areas with the approval of locating devices generating energy from renewable sources. These properties were analyzed in terms of substrate availability (which are waste from animal production, fruit pomace, waste from processing, biomass of plants grown intentionally),plot size, infrastructure status and distance from protected areas. On this basis, one location was chosen that meets all those criteria. Surveys have shown that residents are afraid of unpleasant smell, noise, emerging waste and explosion risk. Nevertheless, the majority of respondents declared willingness to cooperate with the biogas plant.
\end{abstract}

\section{Introduction}

The obligation to achieve a $20 \%$ share of energy from renewable sources (RES) in the total EU energy demand increases the interest in the use of agricultural biogas [1]. Development of agricultural biogas plants contributes to the creation of new workplaces [2], and the use of biogas has a positive effect on the environment by replacing traditional fossil fuels with biomass and reducing emissions to the atmosphere [3].

Localization of agricultural biogas plants raise much controversy in Poland. They provide an opportunity for the development of agriculture, but inhabitants, fearing the nuisance related to their functioning, do not agree on the location near the place of their residence. Location of the biogas plant construction must be appropriately selected taking into account all technical, location and social aspects $[4,5]$.

Agricultural biogas plants are classified as investments with special location requirements, the most important of which are [6]:

- access to raw materials,

- parameters of the property: area, use in the local development plan,

- no spatial conflict with built-up and protected areas,

- access to transport and energy infrastructure,

- possibility of managing the post-ferment residue.

The purpose of the work was to determine spatial conditioning and assessment of social attitudes in connection with the concept of construction of an agricultural biogas plant in the agricultural commune of Kamionka in Lublin province, Poland.

\section{Material and methodology of research}

An analysis of spatial conditions and assessment of social attitudes regarding the construction of an agricultural biogas plant in Kamionka rural commune (Lubartów poviat, Lublin province, Poland) was carried out. There are 6496 inhabitants living in the commune. Field studies, analysis of strategic and planning documents of a local nature [7], legal acts in force, as well as statistical data and geodetic-cartographic materials available at the Commune Office in Kamionka, were also performed. The assessment of social attitudes was carried out using the direct interview method, using a form consisting of 9 questions. The survey covered 50 randomly selected, adult residents of the commune.

\section{Results}

\subsection{Analysis of the substrate market}

An important substrate for agricultural biogas plants is waste from animal production, arising on farms with a large scale of farming. In Kamionka commune, the identification of farms dealing with cattle and pig production has been made. It is assumed that the

* Corresponding author: alina.jusko@up.lublin.pl 
profitability of biogas production takes place in farms with animal husbandry on average above 100 LU (Livestock Unit) [6]. Table 1 presents information about large-scale animal husbandry farms.

According to the Regulation [8], animal conversion factors for LU were adopted, due to which the number of farms with animal husbandry above $100 \mathrm{LU}$ can be determined. The analysis showed that in Kamionka commune, there are 7 farms that meet the above condition, therefore they were included in potential suppliers of substrates for biogas plants.

Table 1. Large-scale animal husbandry farms in Kamionka commune

\begin{tabular}{|c|c|c|c|c|}
\hline Farm area $[\mathrm{ha}]$ & Group of animals & Herd size & LU factor & LU per farm \\
\hline 30 & cows & 155 & 1 & 155 \\
\hline 17 & pigs & 354 & 0.35 & 123.9 \\
\hline 30 & bulls & 200 & 1,4 & 280 \\
\hline 15 & pigs & 550 & 0.35 & 192.5 \\
\hline 13 & pigs & 300 & 0.35 & 105 \\
\hline 30 & cows; bulls & $100 ; 35$ & $1 ; 1.4$ & 149 \\
\hline 52 & bulls & 400 & 1.4 & 560 \\
\hline
\end{tabular}

Source: Own study

The commune also has a soft fruit processing plant that processes chokeberry, blackcurrant and raspberry fruit. In the production process of juices and concentrates, fruit pomace is produced - about 30,000 $\mathrm{Mg}$ annually. Locally available substrate for biogas production may be fruit grown by other agricultural companies operating in the commune. Every year, it produces about $100 \mathrm{Mg}$ of soft fruit. Waste from processing (brewers grains, fruit pomace)is a good substrate for biogas production, however, it is available only seasonally $[9,10]$. In certain cases, when a biogas plant has access to cheap substrates, it may be profitable to transport them also over longer distances [11].

The substrate for biogas production may also consist of the biomass of plants grown intentionally, including maize, grass, rye. Marginal soils, i.e. lower bonitation classes: IVa and b, V, as well as contaminated soils should be allocated under their cultivation. The Kamionka commune has weak soils, with IV class soils predomination (54\% of arable land) and $\mathrm{V}$ class soils (24\%), as well as land not used for agriculture. Therefore, it is possible to designate these areas for purpose crops of biogas plants, especially species with small requirements, such as sorghum or miscanthus [1214].

\subsection{Infrastructure analysis}

When choosing a biogas plant location, access to the infrastructure is important, mainly accessibility and condition of roads due to the need to transport substrates and post-ferment, as well as possibility of connecting to the electricity or gas network. Municipal roads in the Kamionka commune are of poor quality, requiring the surface to be hardened. District roads have better technical condition and they do not have hardened surface only to a small extent. Provincial road requires a thorough renovation. The sale of energy requires access to the power network, the status of which has been rated as good. The problem is network failures and repairs that appear several times a year, especially during unfavorable weather conditions.

The weakness of projects undertaken in Kamionka commune is the lack of a gas network (inhabitants individually supply themselves with liquefied gas), as well as sewage infrastructure. The municipality has 1 mechanical-biological sewage treatment plant, purifying domestic sewage only from the town of Kamionka.

\subsection{Choice of real estate}

When choosing the location for the biogas plant, the areas included in the "Study of conditions and directions of spatial development of the Kamionka commune" [7] were considered as "areas of buildings, services and production facilities, warehouses and stores with the approval of locating devices producing energy from renewable energy sources". Some of these areas are located in protected areas or in their immediate vicinity, thus they have been rejected as a potential place for the location of biogas plants. A total of 9 sites were selected, which were analyzed in terms of distance from protected areas, access to the roads, and also in terms of plot area.

The first criterion assessed was the distance from areas under legal protection. This is particularly important condition to meet in the case of Kamionka commune, which is largely located within protected forests. Areas No. 5 and 8 are located less than $1 \mathrm{~km}$ from the outskirts of the Kozłowiecki Landscape Park, which could cause many problems in the construction of biogas plants, including the lack of obtaining a building permit. These properties were eliminated from further analysis.

The area of the property, on which agricultural biogas plant is planned is an important criterion. It is assumed that minimum plot area for the construction of a biogas plant with a capacity of about $1 \mathrm{MW}_{\mathrm{e}}$ is $2-3$ ha (depending on the storage method of the substrates and other technological solutions). Three of the analyzed properties meet this requirement - No. 2, 3 and 9 (Table 2 ). During the local inspection, it was found that in the case of these plots, there is also the possibility of 
extending the area through the purchase or lease of adjacent land.

When analyzing the condition of roads, properties No. 1, 3 and 5 have access to roads with very good and good technical condition (Table 2). The remaining roads are roads with poor or very poor condition, requiring renovation.

After the above assessment, plots that did not meet the criterion of area and conditions related to spatial conflict with protected areas were rejected. Further analysis of access to the power network, distances from potential substrate suppliers and distances from human habitats were subject for plots No. 2, 3 and 9.

Properties No. 2 and 9 are located at a considerable distance (respectively 0,94 and $1,47 \mathrm{~km}$ ) from the medium voltage line, and thus the connection of a biogas plant to the network carries very high costs. On the other hand, when analyzing the availability of substrates, the areas No. 2 and 3 perform the best. This distance was measured between the areas and the nearest farm with the number of LU>100 pcs. (Table 1).

Table 2. Evaluation of potential areas for biogas plant locations in terms of plot area, distances from protected areas and road infrastructure

\begin{tabular}{|c|c|c|c|c|c|c|c|c|c|c|}
\hline \multicolumn{2}{|c|}{ No of area } & 1. & 2. & 3. & 4. & 5. & 6. & 7. & 8. & 9. \\
\hline \multicolumn{2}{|c|}{ Area [ha] } & 1.59 & 2.16 & 6.47 & 0.49 & 1.72 & 0.94 & 0.75 & 1.61 & 6.25 \\
\hline \multirow{3}{*}{ 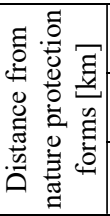 } & $\begin{array}{c}\text { OCK Kozi } \\
\text { Bór }\end{array}$ & 3.63 & 3.90 & 4.00 & 1.28 & 3.14 & 5.18 & 6.12 & 7.00 & 1.68 \\
\hline & $\begin{array}{c}\text { Kozłowiecki } \\
\text { LP }\end{array}$ & 5.27 & 4.66 & 4.06 & 2.47 & 2.25 & 4.05 & 4.71 & 3.44 & 4.30 \\
\hline & $\begin{array}{c}\text { Outskirts of } \\
\text { LP }\end{array}$ & 3.69 & 3.00 & 2.41 & 1.33 & 0.11 & 1.14 & 1.63 & 0.59 & 2.44 \\
\hline \multicolumn{2}{|c|}{ Driveway } & 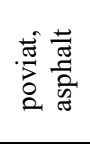 & 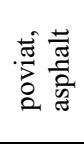 & 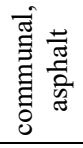 & 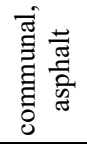 & 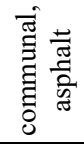 & 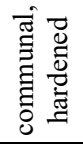 & 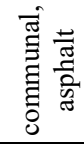 & 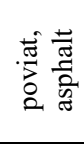 & 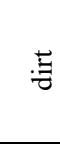 \\
\hline \multicolumn{2}{|c|}{ Condition of driveway } & $\begin{array}{l}\overrightarrow{0} \\
0 \\
0 \\
: \\
0 \\
0\end{array}$ & $\begin{array}{l}0 \\
.\end{array}$ & $\begin{array}{l}0 \\
0 \\
0 \\
00 \\
2 \\
0 \\
>\end{array}$ & $\begin{array}{l}\dot{0} \\
0 \\
2 \\
2 \\
0 \\
0\end{array}$ & 范 & 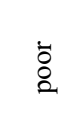 & 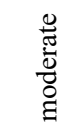 & 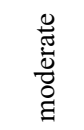 & $\begin{array}{l}\dot{0} \\
8 \\
2 \\
\overrightarrow{0} \\
>\end{array}$ \\
\hline
\end{tabular}

Source: Own study

Analyzing all the criteria, the most favorable assessment was obtained by the investment area No. 3. It is located in the town of Kamionka, and its area (6.47 ha) is sufficient for the location of biogas plant and other buildings and structures associated with the technological sequence. The property is located on an asphalt poviat road with very good condition and in close proximity to the medium voltage power network (Table 3). In addition, the distance of protected areas from plot No. 3 is large and the location of the biogas plant on this property will not threaten the environment. At the same time, it was found that property No. 3 is located closest to human buildings, which on the one hand gives the opportunity to sell heat to residents, and on the other, it can generate protests from the local community. In order to assess this risk, surveys were carried out among residents.

Table 3. Evaluation of potential areas for the location of biogas plants in terms of technical infrastructure, distances from potential suppliers and human habitats

\begin{tabular}{|c|c|c|c|}
\hline \multirow{2}{*}{$\begin{array}{c}\text { No } \\
\text { of } \\
\text { area }\end{array}$} & $\begin{array}{c}\mid 3 \\
\text { power network } \\
15 \mathrm{kV}\end{array}$ & $\begin{array}{c}\text { the nearest } \\
\text { substrate } \\
\text { suppliers }\end{array}$ & $\begin{array}{c}\text { the closest } \\
\text { human } \\
\text { settlements }\end{array}$ \\
\hline 2. & 0.94 & 1.27 & 1.27 \\
\hline 3. & 0.25 & 2.00 & 0.30 \\
\hline 9. & 1.47 & 3.72 & 1.7 \\
\hline
\end{tabular}

Source: Own study

\subsection{Evaluation of social attitudes}

Social issues are important when choosing a biogas plant location. The questionnaire asked about the residents' attitude towards the construction of a biogas plant. Respondents declared having knowledge about the production of energy from renewable sources and energy plants. A significant part of respondents can indicate the raw materials, from which biogas can be produced (Table 4). All respondents believe that the biogas plant is beneficial for the environment, plus $96 \%$ believe that it will allow farmers to earn. Over half $(60 \%)$ of the respondents believe that the biogas plant produces unpleasant odors. A significant part of respondents (over $80 \%$ ) believe that the construction of a biogas plant will have positive impact on the commune - it will protect the environment, provide cheaper energy to the residents, and bring income to farmers by creating additional workplaces and crop sales. Concerns related to the construction of biogas plants are mainly the fear of unpleasant smell, noise, increased amounts of pollution and the risk of explosion. Some of respondents expressed their willingness to cooperate with a biogas plant by supplying substrates, buying energy produced, or using the digestate for fertilizing purposes. 
Table 4. Survey results

\begin{tabular}{|c|c|c|c|}
\hline \multirow{2}{*}{\multicolumn{2}{|c|}{ Question }} & \multicolumn{2}{|c|}{ Answers [\%] } \\
\hline & & Yes & No \\
\hline \multirow{5}{*}{$\begin{array}{l}\text { Do you know that } \\
\text { energy can be } \\
\text { generated from: }\end{array}$} & sun radiation & 100 & 0 \\
\hline & Earth crust & 74 & 26 \\
\hline & water & 94 & 6 \\
\hline & wind & 100 & 0 \\
\hline & biomass & 80 & 20 \\
\hline \multirow{6}{*}{$\begin{array}{l}\text { Do you know } \\
\text { energy plants: }\end{array}$} & willow & 56 & 44 \\
\hline & Virginia mallow & 6 & 94 \\
\hline & miscanthus & 4 & 96 \\
\hline & corn & 64 & 36 \\
\hline & rape & 52 & 48 \\
\hline & Jerusalem artichoke & 4 & 96 \\
\hline \multirow{5}{*}{$\begin{array}{l}\text { Do you think that } \\
\text { the installation for } \\
\text { the production of } \\
\text { energy from } \\
\text { renewable sources } \\
\text { is: }\end{array}$} & beneficial for environment & 98 & 2 \\
\hline & profitable for the user & 98 & 2 \\
\hline & easy in use & 78 & 22 \\
\hline & cheap to construct & 12 & 88 \\
\hline & cheap in use & 50 & 50 \\
\hline \multirow{7}{*}{$\begin{array}{c}\text { Where does your } \\
\text { information on the } \\
\text { biogas plant come } \\
\text { from: }\end{array}$} & press & 30 & \\
\hline & radio & 28 & \\
\hline & television & 34 & \\
\hline & internet & 42 & \\
\hline & practices & 0 & \\
\hline & from friends & 6 & \\
\hline & university/school & 4 & \\
\hline \multirow{7}{*}{$\begin{array}{l}\text { Can biogas be } \\
\text { produced from: }\end{array}$} & plants & 98 & 2 \\
\hline & straw & 66 & 34 \\
\hline & animal waste & 84 & 16 \\
\hline & municipal waste & 62 & 38 \\
\hline & sewage & 44 & 56 \\
\hline & pulp from sugar refineries & 58 & 42 \\
\hline & decoction from the distillery & 58 & 42 \\
\hline \multirow{6}{*}{$\begin{array}{l}\text { Do you think the } \\
\text { biogas plant: }\end{array}$} & is beneficial for environment & 100 & 0 \\
\hline & produces unpleasant smell & 60 & 40 \\
\hline & generates a lot of waste & 18 & 82 \\
\hline & threatens to explode & 28 & 72 \\
\hline & causes a lot of noise & 18 & 82 \\
\hline & lets farmers to earn & 96 & 4 \\
\hline \multirow{6}{*}{$\begin{array}{l}\text { Do you think the } \\
\text { biogas plant in } \\
\text { Kamionka } \\
\text { commune: }\end{array}$} & will give work to residents & 86 & 14 \\
\hline & will bring income to farmers & 88 & 12 \\
\hline & will protect the environment & 94 & 6 \\
\hline & will provide cheaper energy & 92 & 8 \\
\hline & will improve the image of the commune & 86 & 14 \\
\hline & will enrich the commune due to taxes & 82 & 18 \\
\hline \multirow{5}{*}{$\begin{array}{l}\text { What are your } \\
\text { concerns about the } \\
\text { biogas plant: }\end{array}$} & noise & 28 & 72 \\
\hline & waste & 18 & 82 \\
\hline & environment pollution & 28 & 72 \\
\hline & unpleasant odor & 100 & 0 \\
\hline & explosion & 28 & 72 \\
\hline How would you & provide substrates & 66 & \\
\hline like to cooperate & use post-ferment as a fertilizer & 26 & \\
\hline with the biogas & purchase energy & 32 & \\
\hline plant: & I do not want to cooperate with a biogas plant & 34 & \\
\hline
\end{tabular}

\section{Summary and conclusions}

Renewable energy sources play a significant role in the energy balance of communes, poviats and regions. One of them is biogas obtained as a result of methane fermentation in agricultural biogas plants. Choosing the right location requires taking into account many technological, legal, environmental and social issues.
In the studied commune, there was a high potential of substrates for biogas production originating from animal production, fruit production and processing as well as purpose crops. When choosing the location for a biogas plant, places designated in the planning documents of the commune were considered as areas with the possibility of locating devices generating energy from RES. These areas were subjected to a detailed analysis (taking into account the infrastructure, 
plot area and distance from protected areas), due to which one location for a biogas plant was selected, meeting all the criteria assessed.

Surveys have shown that residents have knowledge about agricultural biogas plants, as well as sources of biogas production. The respondents were of the opinion that the biogas plant is beneficial for the environment $(100 \%$ of respondents), will provide cheaper energy ( $92 \%$ of respondents), allow lowering of unemployment ( $86 \%$ of respondents), bring income to farmers ( $88 \%$ of respondents) and improve the image of the commune ( $86 \%$ of respondents). Some residents expressed their concerns about unpleasant odors $(60 \%$ of respondents), noise $(18 \%$ of respondents), pollution (18\% of respondents) and the risk of a biogas plant explosion (28\% of respondents).

\section{Acknowledgements}

Publication supported by the Polish Ministry of Science and Higher Education as a part of the program of activities disseminating science from the project „Organization of the First International Science Conference - Ecological and Environmental Engineering”, 26-29 June 2018, Kraków.

\section{References}

1. M. Powałka, A.M. Klepacka, J. Skudlarski, E. Golisz. Zeszyty Naukowe SGGW. Problemy Rolnictwa Światowego 13 (28), pp. 203-212 (2013)

2. W. Pawłowski. Ecological Engineering 18 (5), pp. 157-169 (2017)

3. A. Jędrczak, Biologiczne przetwarzanie odpadów. PWN, Warszawa (2007)
4. M. Jóźwiak M, Biogazownie rolnicze - mity i fakty. FDPA, Warszawa (2011)

5. A. Kowalczyk-Juśko, R. Świerczyński. Roczniki Naukowe SERiA XIII, 7, pp. 66-70 (2011)

6. Uwarunkowania lokalizacyjne i proces inwestycyjny budowy biogazowni rolniczych w województwie lubelskim. Biuro Planowania Przestrzennego w Lublinie, Lublin (2010)

7. Studium uwarunkowań i kierunków zagospodarowania przestrzennego gminy Kamionka. Przyjęty uchwałą Nr. IV/14/2011 Rady Gminy Kamionka. Kamionka (2011)

8. Rozporządzenie Rady Ministrów z dnia 9 listopada 2010 r. W sprawie określenia rodzajów przedsięwzięć mogących znacząco oddziaływać na środowisko. Dz.U. 2010 Nr 213, poz. 1397

9. W. Czekała, A. Smurzyńska, M. Cieślik, P. Boniecki, K. Kozłowski, Biogas efficiency of selected fresh fruit covered by the Russian embargo. Energy And Clean Technologies Conference Proceedings, SGEM 2016, III, pp. 227-233 (2016)

10. G. Maj, W. Piekarski, A. Kowalczyk-Juśko, A. Łukaszczyk. Przemysł Chemiczny 93/5, pp. 732736 (2014)

11. A. Kowalczyk-Juśko, G. Maj, W. Piekarski, H. Ignaciuk. Logistyka 6, pp. 156-160 (2014)

12. H. Waliszewska, M. Zborowska, B. Waliszewska, S. Borysiak, A. Antczak, W. Czekała. Cellulose 25 (2), pp. 1207-1216 (2018)

13. A. Kowalczyk-Juśko, B. Kościk, K. Jóźwiakowski, A. Marczuk, J. Zarajczyk, J. Kowalczuk, M. Szmigielski, A. Sagan. Przemysł Chemiczny 94/10, pp. 1838-1840 (2015)

14. A. Kowalczyk-Juśko. Przemysł Chemiczny 95/11, pp. 2326-2329 (2016) 